\title{
HETEROGENICZNOŚĆ PRZESTRZENNA POSTAW WYBORCZYCH MIESZKAŃCÓW GMINY UNIEJÓW W WYBORACH EUROPEJSKICH I PARLAMENTARNYCH W 2019 ROKU
}

\begin{abstract}
Zarys treści: Niniejszy artykuł prezentuje zróżnicowanie postaw wyborczych mieszkańców gminy Uniejów podczas głosowań w 2019 r. Wybory, które odbyły się w zeszłym roku, miały charakter zarówno ponadnarodowy (wybory do Parlamentu Europejskiego), jak i krajowy (wybory parlamentarne). Zachowania wyborcze, które uwzględniono w pracy, obejmowały poparcie dla poszczególnych partii oraz frekwencję.
\end{abstract}

Słowa kluczowe: wybory parlamentarne, wybory europejskie, gmina Uniejów

\section{WSTĘP}

Lata 90. ubiegłego wieku to okres zakrojonych na dużą skalę przemian, zarówno w sferze ekonomicznej, gospodarczej, społecznej, ale przede wszystkim politycznej. Te ostanie to skondensowany proces, który doprowadził do wytworzenia czterech podstawowych opcji politycznych. Powstałe wówczas sprzeczności podzieliły polską scenę polityczną na grupy o przeciwstawnych interesach (oś ludowcy i liberałowie) oraz wartościach (oś prawica i lewica) ${ }^{1}$. Rozłam ten ma związek z szeroko pojmowaną aktywnością polityczną, wynikającą m.in. z różnorodności przestrzennej, na którą składają się zarówno czynniki historyczno-kulturowe, jak i ekonomiczno-społeczne.

* Paulina Kurzyk, mgr, asystent, Uniwersytet Łódzki, Wydział Nauk Geograficznych, Instytut Zagospodarowania Środowiska i Polityki Przestrzennej, ul. Kopcińskiego 31, 90-142 Łódź, e-mail: paulina.kurzyk@geo.uni.lodz.pl

1 M. Kowalski, Zachowania wyborcze ludności wiejskiej a sytuacja społeczno-ekonomiczna wsi-identyfikacja procesów, „Studia Obszarów Wiejskich” 2004, t. 6, s. 132. 
Zachowania wyborcze, a więc ogół postaw przyjętych przez obywateli w związku z wyborami, mogą przybierać różne formy. Począwszy od samego zainteresowania głosowaniem, poprzez uczestnictwo bądź absencję, wyrażanie preferencji, a także udział w kampanii wyborczej, a skończywszy na postawie pasyw$n^{2}{ }^{2}$. W literaturze przedmiotu prezentowane są dwa podejścia względem zachowań wyborczych w ujęciu przestrzennym. Według J. Hryniewicza i B. Jałowieckiego (1997) stosunek do wyborów to wynik zaszłości historycznych, w szczególności okresu zaborów, które warunkują zróżnicowanie kapitału społecznego, a tym samym aktywność społeczną ${ }^{3}$. Drugie podejście zakłada, że główną determinantą tego zjawiska jest aktualna sytuacja gospodarcza i społeczna w kraju, którą oddają analizy statystyczne, ujawniając dysproporcje rozwojowe w wymiarze zarówno społecznym, jak i ekonomicznym. Te z kolei mogą wpływać na unifikowanie postaw wyborczych ${ }^{4}$. Według M. Kowalskiego (2004) ${ }^{5}$ frekwencja wyborcza najwyższa jest na obszarach dawnych zaborów pruskiego i austriackiego, co wynika z wyższego poziomu wykształcenia mieszkańców oraz ich religijności.

Poniższy artykuł ma na celu zobrazowanie różnorodności postaw wyborczych bądź jej braku podczas ostatnich wyborów krajowych i ponadnarodowych. Zjawisko to warte jest uwagi głównie dlatego, że obszar badawczy znajduje się jednocześnie na obu liniach antagonistycznych ośrodków politycznych. Pierwszy podział, wynikający z uwarunkowań historyczno-kulturowych, dzielący na lewicę i prawicę, należy odnieść w tym przypadku do położenia gminy Uniejów, która znajduje się niejako na styku historycznego zaboru pruskiego i Królestwa Polskiego. Ponadto badana gmina to ośrodek o charakterze miejsko-wiejskim, a więc takim, gdzie główne różnice odnoszą się do kontrastów między ludowcami a liberałami, czyli rozkładu na tzw. osi interesów.

M. Sobczyński twierdzi, że geograf badając zachowania wyborcze, powinien wziąć pod uwagę dwa aspekty, tj. preferencje wyborcze oraz stosunek do aktu wyborczego, a więc frekwencję lub absencję ${ }^{6}$. Podczas pracy nad artykułem poddano analizie wyniki wyborów do Parlamentu Europejskiego w latach 2014 i 2019 oraz Sejmu i Senatu RP. Dane te zostały opublikowane przez Państwową Komisję Wyborczą (PKW). Analizy o podobnym charakterze dla tego obszaru zostały

2 J. Raciborski, Polskie wybory. Zachowania wyborcze spoleczeństwa polskiego $w$ latach 1989-1995, Wydawnictwo Naukowe „Scholar”, Warszawa 1997, s. 158.

3 J. Hryniewicz, B. Jałowiecki, System polityczny a rozwój gospodarczy, „Studia Regionalne i Lokalne" 1997, t. 20, nr 53, s. 13-63.

4 P. Krzemiński, Zachowania wyborcze $w$ wyborach parlamentarnych i prezydenckich w Polsce w latach 2005-2007 - wzory przestrzennych zróżnicowań, „Przegląd Geograficzny” 2009, t. 81, nr 2, s. 259-281.

5 M. Kowalski, Zachowania wyborcze ludności wiejskiej..., s. 135.

6 M. Sobczyński, Kilka uwag o metodologii geografii wyborczej wielkiego miasta w Polsce, [w:] M. Kowalski (red.), Przestrzeń wyborcza Polski, Oddział Akademicki PTG, IGiPZ PAN, Warszawa 2003, s. 117. 
przeprowadzone w 2015 roku przez M. Kowalskiego i M. Rożniatę 7 Badania zrealizowano wówczas, biorąc pod uwagę wybory prezydenckie i parlamentarne. Wykazano, że podział elektoratu w stosunku do miejsca zamieszkania (miasto-wieś) oraz uczestnictwo w wyborach w gminie Uniejów nie różni się zasadniczo od innych tego typu obszarów. Dodatkowo autorzy wysnuli wniosek, że wyniki wyborów z 2015 roku mogą mieć charakter incydentalny ${ }^{8}$. Niniejsza praca umożliwi zatem ocenę trendów politycznych oraz poziom aktywności wyborczej mieszkańców gminy Uniejów z uwzględnieniem postaw wyborczych w wyborach europejskich. Do prezentacji przestrzennego podziału elektoratu użyto metod kartograficznych, natomiast zachowania wyborcze opisano za pomocą metod statystycznych.

Teren gminy Uniejów podzielony jest na sześć obwodów wyborczych. Pierwsze cztery obejmują obszary typowo wiejskie, natomiast dwa pozostałe to teren miasta Uniejów (ryc. 1).

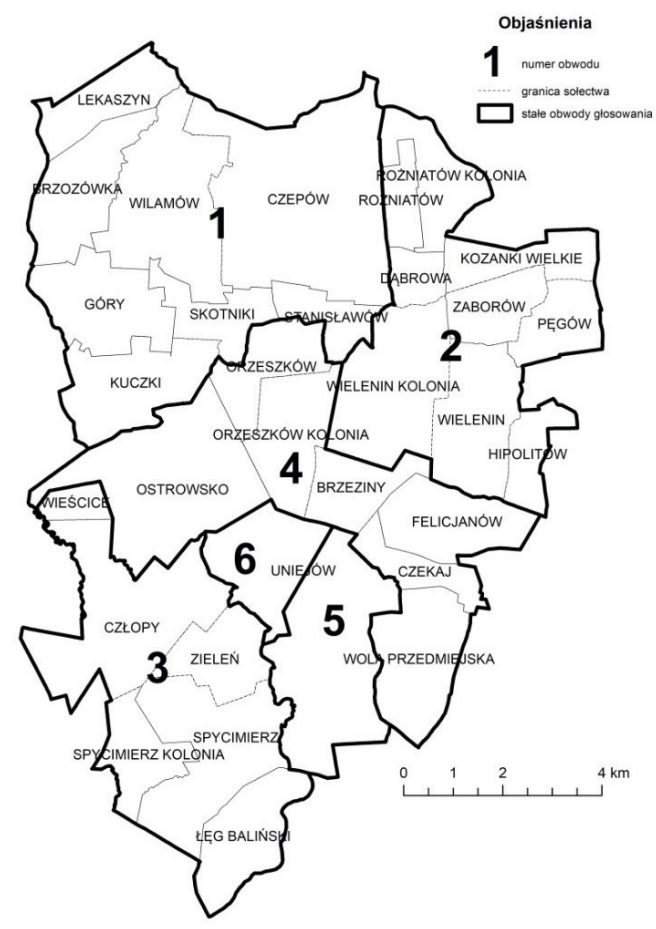

Ryc. 1. Podział gminy Uniejów na obwody głosowań w wyborach w 2019 r.

Źródło: opracowanie własne

7 M. Kowalski, M. Rożniata, Zróżnicowanie przestrzenne zachowań wyborczych mieszkańców gminy Uniejów w wyborach prezydenckich i parlamentarnych w 2015 roku, „Biuletyn Uniejowski” 2016, t. 5, s. 129-142.

8 Tamże. 


\section{WYBORY DO PARLAMENTU EUROPEJSKIEGO}

Według J. Osińskiego i B. Pytlika Parlament Europejski (PE) to swego rodzaju precedens $\mathrm{w}$ skali światowej, ponieważ jest to jedyne zgromadzenie ponadnarodowe wybierane co pięć lat przez ludność w wyborach powszechnych i bezpośrednich. Mimo, że w wielu kwestiach różni się od parlamentów narodowych, stanowi reprezentację ogółu społeczeństwa europejskiego, a tym samym odzwierciedlenie jego woli i przekonań ${ }^{9}$. Rozpatrując genezę PE, należy sięgnąć aż do chwili powstania Unii Europejskiej (UE), a więc do roku 1952, kiedy to doszło do podpisania traktatu paryskiego i powstania Europejskiej Wspólnoty Węgla i Stali. Na mocy tego porozumienia powstało Zgromadzenie, oddające pierwotny kształt i obraz dzisiejszego PE. Na początku swojej działalności liczyło ono zaledwie 78 przedstawicieli, co związane było z liczbą państw wchodzących w skład wspomnianej powyżej wspólnoty. 25 marca 1957 roku w Rzymie podpisano tzw. traktaty rzymskie, które powołały do życia Europejską Wspólnotę Gospodarczą (EWG) i Europejską Wspólnotę Energii Atomowej (EURATOM). Po wprowadzeniu ich w życie od dnia 1 stycznia 1958 roku na europejskiej scenie politycznej zaczęło funkcjonować Europejskie Zgromadzenie Parlamentarne liczące 142 członków, które 30 marca 1960 roku przyjęło nazwę Parlamentu Europejskiego. Potwierdzenie wyłonienia takiego organu zostało ponadto zawarte w Jednolitym Akcie Europejskim podpisanym w 1986 roku w Luksemburgu i w Hadze. Od 1 listopada 1993 roku PE jest organem UE ${ }^{10}$.

Skupiając się na popularności wyborów do PE w Polsce, należy zaznaczyć, że nie są to wybory cieszące się dużą frekwencją. Źródła tego stanu należy doszukiwać się w specyfice życia politycznego naszego kraju oraz w pozycji, jaką w opinii i świadomości Polaków ma Unia Europejska. Zdaniem M. Rulki wybory do PE należy traktować pod względem frekwencji jako trzeciorzędne, ponieważ poziom uczestnictwa w tym głosowaniu jest mniejszy niż w wyborach parlamentarnych, prezydenckich, jak również samorządowych ${ }^{11}$.

Dnia 25 maja 2014 roku odbyły się w Polsce wybory do PE. Wybrano 51 europosłów wchodzących w skład PE liczącego 751 eurodeputowanych. W wyborach wzięło udział blisko 7,3 mln uprawnionych Polaków, co stanowiło o frekwencji $23,83 \%{ }^{12}$. Gmina Uniejów, położona w powiecie poddębickim, zanotowała niż-

9 J. Osiński, B. Pytlik, Wybory do Parlamentu Europejskiego w Polsce, „Kwartalnik Kolegium Ekonomiczno-Społecznego. Studia i Prace” 2016, t. 3, s. 11-39.

${ }^{10}$ N. Krzyżanowska, O nierówności płci w sferze publicznej na przykładzie wyborów do Parlamentu Europejskiego 2004, [w:] G. Woźniak (red.), Nierówności społeczne a wzrost gospodarczy w obliczu regionalizacji i globalizacji, Wyd. Uniwersytetu Rzeszowskiego, Rzeszów 2006, s. 397.

${ }^{11}$ M. Rulka, Problem niskiej frekwencji w wyborach do Parlamentu Europejskiego - przyczyny i sposoby jej zwiększenia, „Przegląd Politologiczny” 2010, t. 1, s. 115-124.

${ }^{12} \mathrm{https}: / /$ pe2014.pkw.gov.pl/pl/ [dostęp: 9.12.2019] 
szą frekwencję w stosunku do średniej ogólnokrajowej, jak i tej, jaką wykazało się województwo łódzkie - 23,73\%. Spośród gmin wchodzących w skład powiatu poddębickiego osiągnęła natomiast najlepszy wynik, wynoszący $22,75 \%$. Jednocześnie pozwoliło to uzyskać zdecydowanie lepszy wynik niż średnia dla całego powiatu, która wyniosła 19,56\%.

Ostatnie wybory do PE, które odbyły się 26 maja 2019 roku, z rekordową frekwencją w skali ogólnopolskiej $-45,68 \%{ }^{13}$, w analizowanej gminie cieszyły się również dużym zainteresowaniem. Mieszkańcy gminy Uniejów, podobnie jak w poprzednich wyborach do PE, chętniej oddawali swoje głosy niż w przypadku ludności zamieszkującej pozostałe gminy powiatu poddębickiego, tym samym uzyskując wynik wyższy o blisko 20 p.p., czyli 43,97\%. Była to również zdecydowanie większa frekwencja niż ta, którą zanotował powiat poddębicki (40,57\%), ale niższa niż wartość osiągnięta przez województwo łódzkie $-46,92 \%{ }^{14}$. Warto zaznaczyć, że frekwencja na badanym obszarze była o ponad 4 p.p. ${ }^{15}$ większa niż wartość średnia - 39,03\% ${ }^{16}$, osiągnięta przez gminy, które zamieszkuje od 5 do 10 tysięcy osób, a więc takie, do których zalicza się gmina Uniejów.

Analizując frekwencję w wyborach do PE w latach 2014 i 2019 na obszarze gminy Uniejów, należy stwierdzić, że zmianie nie uległa jedynie liczba mieszkańców biorąca udział w wyborach, ale zmienił się jej rozkład przestrzenny. Podczas wyborów w 2019 roku najwyższą frekwencję zanotowano w obwodzie numer sześć, obejmującym północną część miasta Uniejów, przy jednym z niższych wyników podczas wyborów w 2014 roku. W obwodzie tym frekwencja podczas wyborów do $\mathrm{PE} \mathrm{w}$ ostatnim głosowaniu wyniosła niemal 51\%, natomiast pięć lat wcześniej była aż dwukrotnie niższa (27,37\%). Co interesujące, w 2019 roku obwód ten osiągnął wynik zdecydowanie lepszy niż południowe części miasta, natomiast w wyborach w 2014 roku sytuacja wyglądała odwrotnie. Zgodnie z tym, co zaprezentowano na ryc. 2, można stwierdzić, że cechą łączącą obydwa głosowania, nie biorąc pod uwagę wartości bezwzględnych, jest najniższa frekwencja w północnych granicach gminy, czyli obwodach numer jeden i dwa. Po porównaniu obydwu głosowań, przy jednoczesnym uwzględnieniu poziomu uczestnictwa w wyborach osób uprawnionych, nasuwa się wniosek, że południowe części gminy Uniejów były bardziej zaangażowane w wybory do PE. Przyczyn takiej frekwencji można doszukiwać się w tradycyjnym zróżnicowaniu zachowań wyborczych podzielonych na miasto i wieś, gdzie obszary wiejskie charakteryzują się mniejszą liczbą osób uczestniczących w wyborach, a gmina Uniejów w ujęciu demograficznym to gmina miejsko-wiejska z dominującą częścią wiejską ${ }^{17}$.

${ }^{13}$ https://pe2019.pkw.gov.pl/pe2019/pl/frekwencja/pl [dostęp: 10.12.2019]

14 Tamże.

15 Tamże.

16 Tamże.

${ }^{17}$ M. Kowalski, M. Rożniata, Zróżnicowanie przestrzenne zachowań wyborczych..., s. 133. 

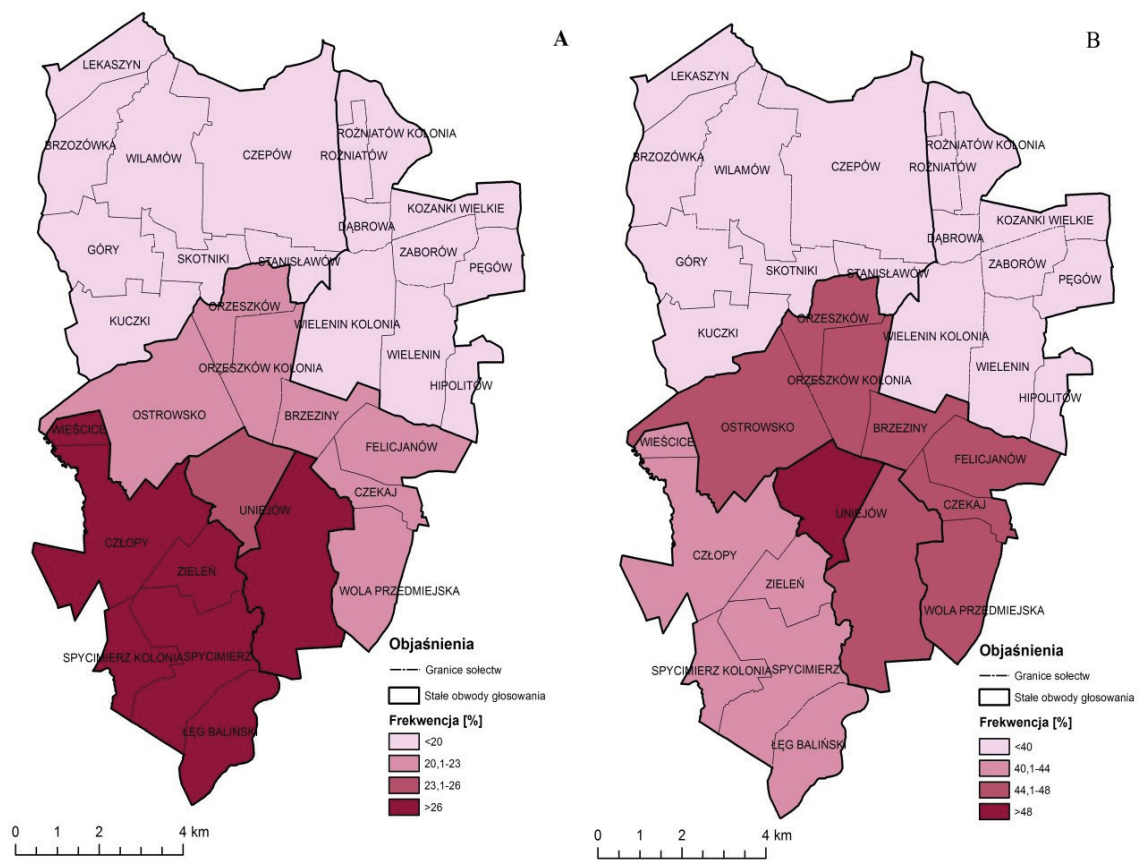

Ryc. 2. Frekwencja wyborcza w gminie Uniejów w wyborach do PE w latach 2014 (A) i 2019 (B) Źródło: opracowanie własne na podstawie danych PKW

Wyborcy podczas wyborów do PE w 2014 r. mogli oddawać głosy aż na 12 list wyborczych. W wymiarze ogólnopolskim wybory te wygrała lista numer 8 , a więc Komitet Wyborczy Platformy Obywatelskiej RP(PO), uzyskując poparcie na poziomie 32,13\%. Jednakże biorąc pod uwagę wyniki dla województwa łódzkiego, w powiecie poddębickim oraz gminie Uniejów zdecydowanym zwycięzcą okazał się Komitet Wyborczy Prawo i Sprawiedliwość (PiS), uzyskując odpowiednio $37,92 \%, 45,48 \%$ i 50,45\% poparcia wśród głosujących. Przyczyn takiego wyniku należy doszukiwać się w geograficznym podziale elektoratów utrzymującym się od lat 90. XX wieku, wedle którego obszar gminy Uniejów to tereny należące niegdyś do tzw. Kongresówki, której ziemie w znacznym stopniu wykazują się większym poparciem dla kandydatów i partii prawicowych ${ }^{18}$, do których zaliczyć możemy PiS.

${ }^{18}$ M. Kowalski, Polaryzacja zachowań wyborczych w Polsce jako rezultat cywilizacyjnego rozdarcia kraju, [w:] M. Kowalski (red.), Przestrzeń wyborcza Polski, Oddział Akademicki PTG, IGiPZ PAN, Warszawa 2003, s.17. 


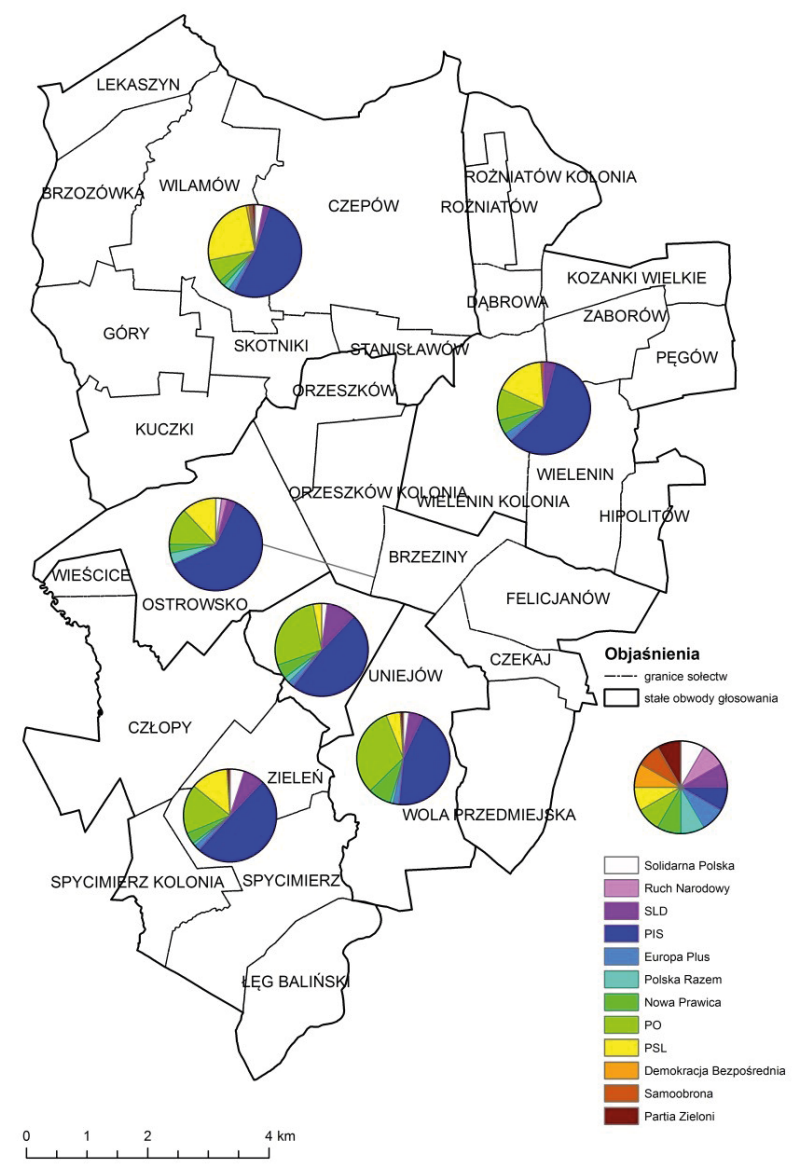

Ryc. 3. Wyniki wyborów do PE w gminie Uniejów w 2014 r.

Źródło: opracowanie własne na podstawie danych PKW

Lista, która osiągnęła najlepsze wyniki, wygrała we wszystkich obwodach znajdujących się na terenie analizowanej gminy (ryc. 3). Ugrupowaniem, które obok PiS uzyskało największe poparcie, było Polskie Stronnictwo Ludowe (PSL), a więc partia ludowa, co również może potwierdzać wcześniej wspomniany podział elektoratu wyborczego Polski. Należy także zauważyć, że PSL zdobył znaczącą przewagę nad ugrupowaniem plasującym się na trzeciej pozycji (PO) na obszarach typowo wiejskich, odmiennie sytuacja wyglądała jedynie w przypadku obwodów numer 5 i 6 , a więc miasta Uniejów. W wyniku przeprowadzonych wyborów mandaty z okręgu numer 6 , w którym położona jest gmina Uniejów, otrzymali dwaj europosłowie - Janusz Wojciechowski z ramienia PiS i Jacek Saryusz-Wolski 
z PO ${ }^{19}$. Wyniki wyborów do PE, które odbyły się w 2019 roku, pozwalają na potwierdzenie i wskazanie pewnych prawidłowości co do preferencji wyborczych mieszkańców gminy Uniejów w tego typu wyborach. Trudno jednak, ze względu chociażby na liczbę zgłoszonych list, jasno porównywać jedno i drugie głosowanie. Podczas wyborów do PE na kadencję 2019-2024 wyborcy mogli dokonać wyboru kandydata spośród 6 list, a więc posiadali o połowę mniejszy wachlarz możliwości wyborczych niż w przypadku wcześniejszego głosowania. Podczas ostatnich wyborów do PE na terenie gminy Uniejów głosy oddane na listy wyborcze rozłożyły się identycznie, zarówno w skali ogólnopolskiej, jak i wojewódzkiej czy powiatowej. Zwycięstwo odniósł po raz kolejny Komitet Wyborczy PiS, uzyskując $62,10 \%$ głosów poparcia wszystkich mieszkańców gminy Uniejów (ryc. 4). Miejsce drugie przypadło Koalicji Europejskiej, a więc połączonym siłom partii PO, PSL, SLD i Partii Zielonych, typowych stronnictw lewicowych i ludowych ${ }^{20}$. Wynik tego głosowania na analizowanym obszarze pozwala jednoznacznie wskazać przewagę prawicy nad pozostałymi opcjami politycznymi.

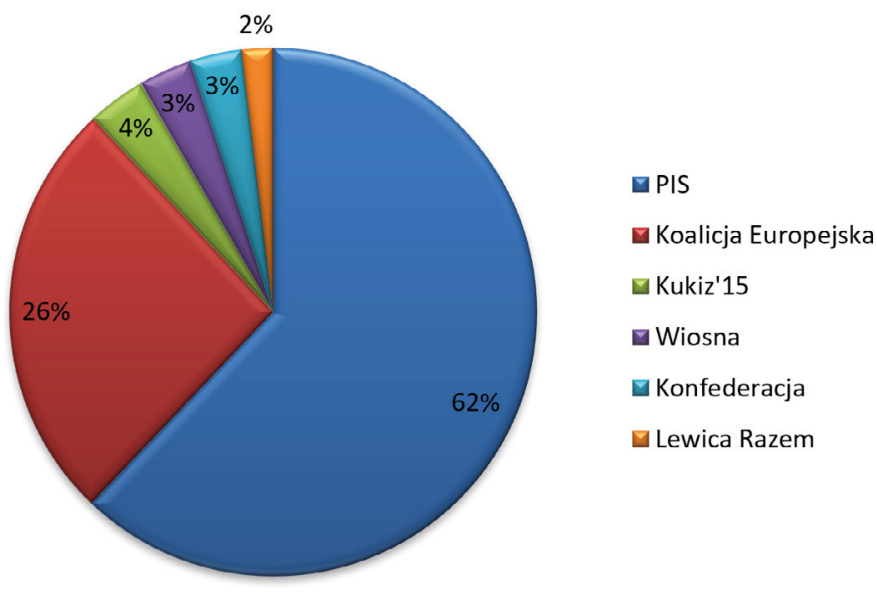

Ryc. 4. Wyniki wyborów do PE w 2019 r. w gminie Uniejów w ujęciu partii politycznych Źródło: opracowanie własne na podstawie danych z PKW

Podobnie jak w wyborach w 2014 roku partia, której lista wygrała w całej gminie, zdobyła również pierwsze miejsce w poszczególnych obwodach. Mniejsze poparcie dla kandydatów PiS zarejestrowano jedynie na obszarze odwodów numer 5 i 6, a więc miasta Uniejów (ryc. 5).

${ }^{19}$ https://pe2014.pkw.gov.pl/pl/pliki.html [dostęp: 10.12.2019]

${ }^{20}$ J. Bański, M. Kowalski, M. Mazur, Zachowania wyborcze mieszkańców polskiej wsi, „Przegląd Geograficzny” 2009, t. 81, nr 4, s. 487. 


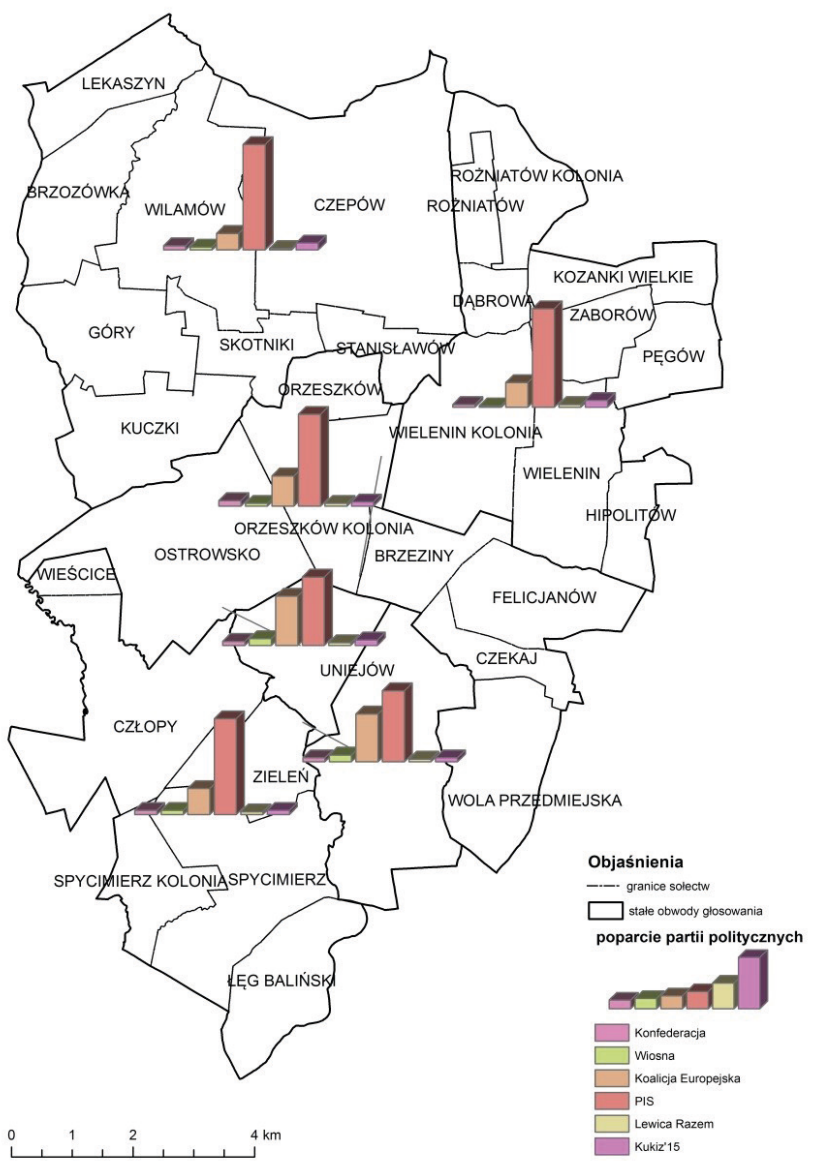

Ryc. 5. Wyniki wyborów do PE w gminie Uniejów w 2019 r. Źródło: opracowanie własne na podstawie danych PKW

\section{WYBORY DO SEJMU I SENATU RZECZPOSPOLITEJ POLSKIEJ W GMINIE UNIEJÓW W 2019 ROKU}

Wybory parlamentarne, które odbyły się 13 października 2019 roku, to kolejna ze składowych odnoszących się do badań nad heterogenicznością zachowań wyborczych analizowanego obszaru. Frekwencja wyborcza w gminie Uniejów wyniosła finalnie $59,76 \%$, tym samym była większa o ponad 10 p.p. od wartości z 2015 roku $(48,31 \%)^{21}$. Należy jednak zaznaczyć, że poziom ten był niższy od wartości zanotowanej w skali 
krajowej oraz wojewódzkiej, które wynosiły odpowiednio 61,74\% i 63,51\%. Jednakże, podobnie jak w przypadku eurowyborów odbywających się w tym samym roku, gmina Uniejów osiągnęła najlepszy wynik spośród wszystkich gmin powiatu poddębickiego. Podążając za ogólnie przyjętą tezą, że mieszkańcy obszarów wiejskich w mniejszym stopniu uczestniczą w wyborach, przeanalizowano poziom frekwencji, konfrontując ze sobą obwód obejmujący miasto Uniejów i tereny wiejskie. Wynik potwierdza, że to właśnie mieszkańcy miasta $(62,62 \%)$ charakteryzują się większym zaangażowaniem politycznym aniżeli ludność zamieszkująca obszary wiejskie $(55,84 \%)$. Najniższy poziom w przypadku omawianego zjawiska zanotowano w obwodzie numer 2 , a więc w sołectwach położonych na północny wschód od głównej jednostki miejskiej (ryc. 6).

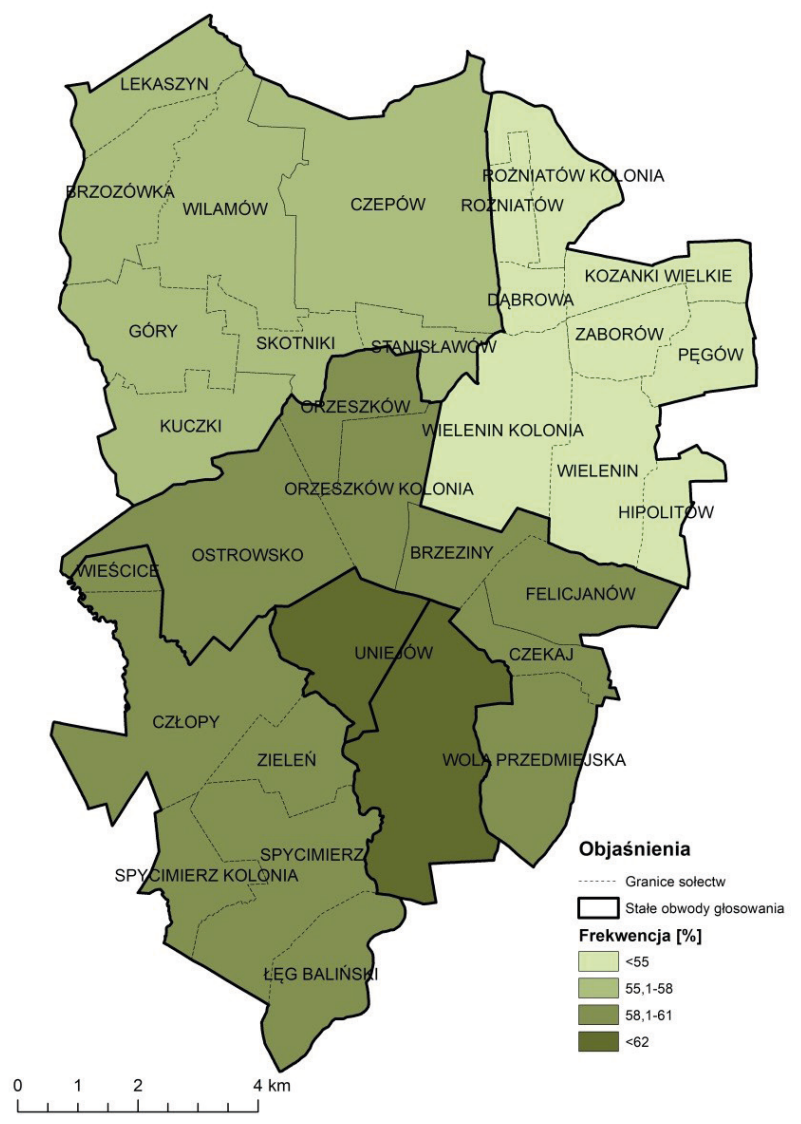

Ryc. 6. Frekwencja w wyborach do Sejmu i Senatu w gminie Uniejów w 2019 r. Źródło: opracowanie własne na podstawie danych z PKW 
Głosujący dokonując wyboru posłów, mogli wskazać na jedną spośród 6 list wyborczych, a więc posiadali niemal ten sam wachlarz możliwości co w odniesieniu do eurowyborów. Porównując wybory do PE z wyborami parlamentarnymi, w obu przypadkach daje się zauważyć znaczącą przewagę PiS. Partia ta zdobyła ponad 50\% głosów, niemal w każdym okręgu wyborczym. Jedynym wyjątkiem jest okręg obejmujący miasto Uniejów (ryc. 7), co po raz kolejny świadczy o słuszności przyjętej tezy, dotyczącej prawicowych upodobań mieszkańców obszarów wiejskich. Drugą co do poziomu poparcia partią okazała się Koalicja Obywatelska. Rozkład głosów w gminie Uniejów wygląda podobnie, jak w przypadku wyborów w 2015 roku. Wtedy również zwycięskim ugrupowaniem został PiS, natomiast $\mathrm{KO}$ (startująca w poprzednich wyborach głównie jako Platforma Obywatelska), odnotowała niższy wynik niż partie ludowe. $Z$ grona 12 wybranych posłów 7 to przedstawiciele PIS-u, spośród których na pierwszym miejscu po raz kolejny znalazł się Piotr Polak.

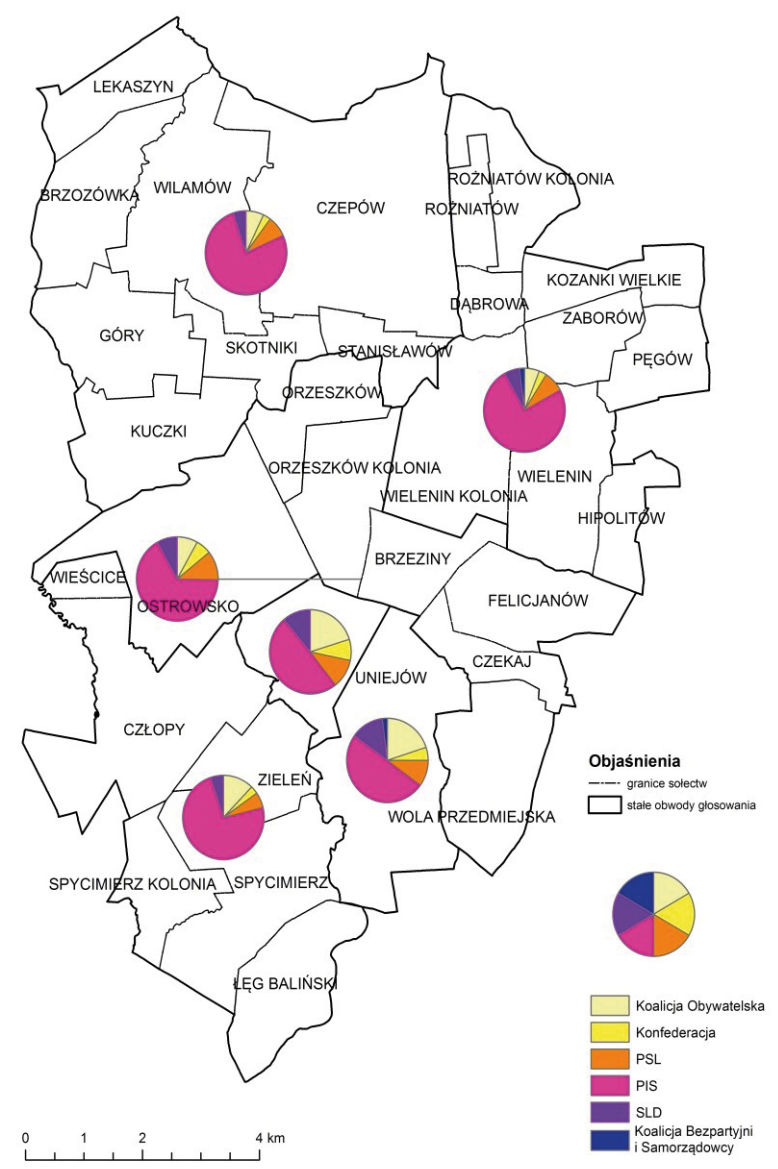

Ryc. 7. Wyniki wyborów do Sejmu w gminie Uniejów w 2019 r.

Źródło: opracowanie własne na podstawie danych PKW 
W wyborach do wyższej izby parlamentu z okręgu numer 25 wystartowało trzech kandydatów. Sytuacja wyglądała niemal analogicznie do tej, która miała miejsce w 2015 roku. Zaskoczenie może budzić jedynie fakt, że wśród kandydatów nie znalazł się żaden przedstawiciel z ramienia PSL.

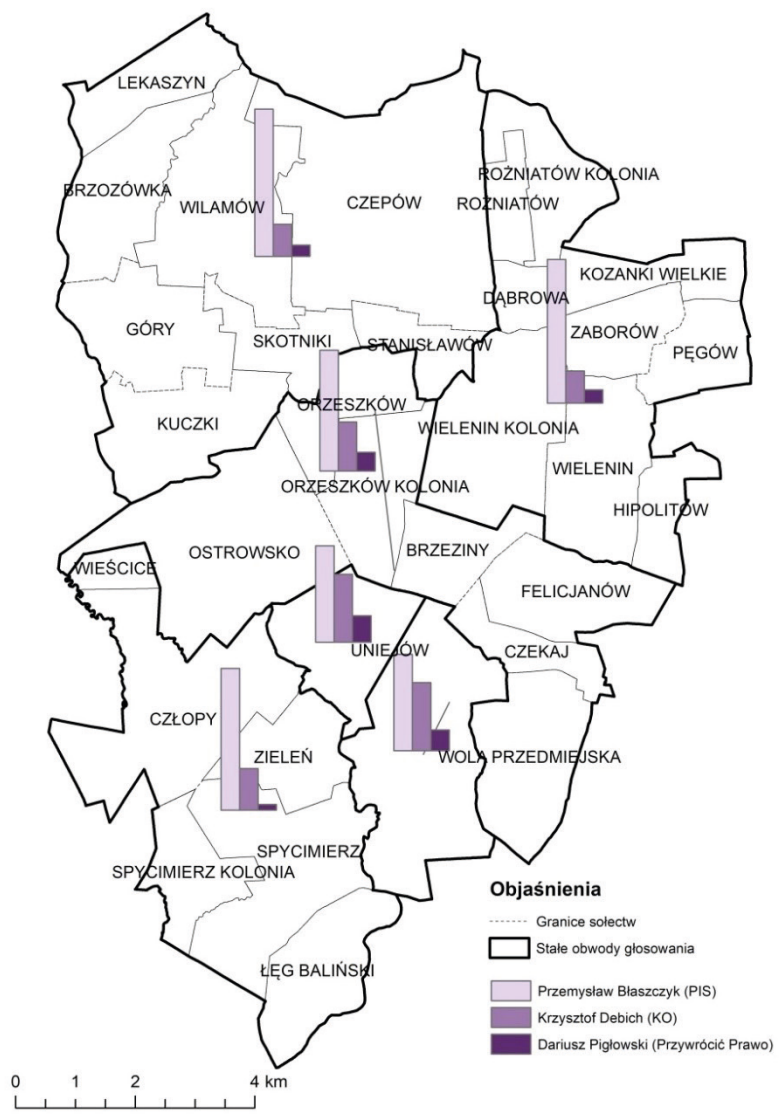

Ryc. 8. Wyniki wyborów do Senatu RP w gminie Uniejów w 2019 r.

Źródło: opracowanie własne na podstawie PKW

Wybory w gminie Uniejów w 2019 r. wygrał przedstawiciel PIS, Przemysław Błaszczyk, uzyskując $62,79 \%$ wszystkich głosów, tym samym zapewniając sobie mandat senatora na kolejną kadencję. Miejsce drugie w omawianych wyborach zajął kandydat z ramienia Koalicji Obywatelskiej - Krzysztof Debich, uzyskując 27,97\%. Ostatnie miejsce przypadło Dariuszowi Pigłowskiemu z Komitetu Wyborczego „Przywrócić Wolność” z wynikiem 9,24\%. Kandydat PiS wygrał 
wybory w każdym z obwodów. Jak wynika z ryc. 8, jedynym konkurencyjnym obszarem jest teren miasta Uniejów, gdzie jego przewaga nad kandydatem KO była stosunkowo niewielka. Zaprezentowane wyniki jednoznacznie pozwalają skonstatować, że również w tym przypadku potwierdza się dominacja PiS-u w gminie Uniejów we wszystkich wyborach odbywających się w 2019 roku.

\section{WNIOSKI}

Mieszkańcy gminy Uniejów na przestrzeni ostatnich 10 lat coraz chętniej uczestniczą w wyborach. Frekwencja na omawianym obszarze, zarówno w głosowaniu o charakterze ponadnarodowym, jak i krajowym w 2019 roku, wzrosła średnio o 20 p.p. Postawy wyborcze przyjmowane przez mieszkańców analizowanej gminy różnią się jednak nieznacznie w zależności od miejsca zamieszkania (większą frekwencję notuje się na obszarze typowo miejskim, a więc na terenie miasta Uniejów).

Na obszarze gminy, podobnie jak w 2015 roku, zdecydowanie uwidocznił się podział na oś interesów i wartości. Scenę polityczną w tej części kraju zdominowało poparcie dla partii prawicowej, co nasuwa wniosek, że na obszarze tym dominuje oś wartości, a heterogeniczność przestrzenna w tym aspekcie prawie w ogóle nie występuje. Poparcie dla prawicy jest potwierdzeniem założenia, że tereny dawnego Królestwa Polskiego charakteryzują się większą aprobatą dla tej opcji. Obszar miejski gminy to także wpływy osi interesów, ujawniające się większym poparciem liberałów niż ludowców. Wyniki zaprezentowane w powyższym artykule pozwalają ponadto potwierdzić prawidłowości zauważone przez M. Kowalskiego i M. Różniatę w 2015 roku $^{22}$. Dodatkowo należy podkreślić, że poparcie dla prawicy na tym obszarze jest coraz bardziej ugruntowane.

\section{Bibliografia}

Bański J., Kowalski M., Mazur M., Zachowania wyborcze mieszkańców polskiej wsi, „Przegląd Geograficzny" 2009, t. 81, nr 4, s. 487.

Hryniewicz J., Jałowiecki B., System polityczny a rozwój gospodarczy, „Studia Regionalne i Lokalne" 1997, t. 20, nr 53, s. 13-63.

Kowalski M., Polaryzacja zachowań wyborczych w Polsce jako rezultat cywilizacyjnego rozdarcia kraju, [w:] M. Kowalski (red.), Przestrzeń wyborcza Polski, Oddział Akademicki PTG, IGiPZ PAN, Warszawa 2003, s. 11-78.

Kowalski M., Zachowania wyborcze ludności wiejskiej a sytuacja społeczno-ekonomiczna wsi - identyfikacja procesów, „Studia Obszarów Wiejskich” 2004, t. 6, s. 132-135.

${ }^{22}$ M. Kowalski, M. Rożniata, Zróżnicowanie przestrzenne zachowań wyborczych..., s. 129-142. 
Kowalski M., Rożniata M., Zróżnicowanie przestrzenne zachowań wyborczych mieszkańców gminy Uniejów w wyborach prezydenckich i parlamentarnych $w 2015$ roku, ,Biuletyn Uniejowski" 2016, t. 4, s. 129-142.

Krzemiński P., Zachowania wyborcze $w$ wyborach parlamentarnych i prezydenckich $w$ Polsce w latach 2005-2007 - wzory przestrzennych zróżnicowań, „Przegląd Geograficzny” 2009, t. 81, nr 2, s. 259-281.

Krzyżanowska N., O nierówności płci w sferze publicznej na przykładzie wyborów do Parlamentu Europejskiego 2004, [w:] G. Woźniak (red.), Nierówności spoteczne a wzrost gospodarczy w obliczu regionalizacji i globalizacji, Wyd. Uniwersytetu Rzeszowskiego, Rzeszów 2006, s. 391-411.

Osiński J., Pytlik B, Wybory do Parlamentu Europejskiego w Polsce , „Kwartalnik Kolegium Ekonomiczno-Społecznego. Studia i Prace" 2016, t. 3, s.11-39.

Raciborski J., Polskie wybory. Zachowania wyborcze społeczeństwa polskiego $w$ latach 1989-1995, Wydawnictwo Naukowe „Scholar”, Warszawa 1997.

Rulka M., Problem niskiej frekwencji w wyborach do Parlamentu Europejskiego - przyczyny i sposoby jej zwiększenia, „Przegląd Politologiczny” 2010, t. 1, s. 115-124.

Sobczyński M., Kilka uwag o metodologii geografii wyborczej wielkiego miasta $w$ Polsce, [w:] M. Kowalski (red.), Przestrzeń wyborcza Polski, Oddział Akademicki PTG, IGiPZ PAN, Warszawa 2003, s. 115-130.

\section{Źródła internetowe}

https://pe2014.pkw.gov.pl/pl/ [dostęp: 9.12.2019]

https://pe2019.pkw.gov.pl/pe2019/pl/frekwencja/pl [dostęp: 10.12.2019]

https://parlament2015.pkw.gov.pl/349_Wyniki_Sejm/0/0/11/101902.html [dostęp: 12.12.2019]

\section{SPATIAL HETEROGENEITY OF ELECTORAL CHOICES OF UNIEJÓW MUNICIPALITY INHABITANTS IN 2019 EUROPEAN AND PARLIAMENTARY ELECTIONS}

\section{Summary}

This article presents the variety of electoral choices of Uniejów municipality inhabitants in 2019 elections, which had a supranational (European Parliament) as well as a national (Polish Parliament) dimension. The electoral decisions that were taken into account in this study included support for the different parties and voter turnout.

Keywords: parliamentary elections, European elections, Uniejów municipality

Data nadesłania artykułu: marzec 2020

Data akceptacji: kwiecień 2020 